\title{
IGNAZ SEMMELWEIS, CARL MAYRHOFER, AND THE RISE OF GERM THEORY
}

\author{
by
}

\section{K. CODELL CARTER*}

Research interests in late nineteenth-century medicine focused heavily on aetiologya subject that one contemporary writer called "the chief science of medicine". ${ }^{1}$ The quest for necessary causes of specific diseases characterized not only research on the infectious diseases but also on psychological disorders and the deficiency diseases. ${ }^{2}$ In a sense, all of these investigations rested on the assumption that each specific disease had a necessary cause. In fact, this assumption would have been false given the symptomatic and anatomical characterizations that prevailed in medicine until the late nineteenth century; any physical state such as a collection of symptoms or an anatomical lesion can, in principle, be caused in many different ways. The adoption of aetiological characterizations for specific diseases, which made it true by definition that each characterized disease had a necessary cause, was, therefore, essential to research of this kind.

In an earlier paper I argued that Ignaz Semmelweis's account of childbed fever, like the aetiological accounts of the infectious diseases that were generated a few decades later, also rested on the assumption that a single necessary cause could be identified for every case of this disease. ${ }^{3}$ No one who originally responded to Semmelweis's work, including those who are generally identified as his supporters, accepted this assumption, and, indeed, nearly everyone explicitly rejected it. ${ }^{4}$ This hostile reaction suggests that the approach was unfamiliar, that Semmelweis may have been among the first to have adopted it. If so, one might wonder whether this aspect of Semmelweis's work significantly influenced subsequent medical thought. Semmelweis's many commentators have discussed exhaustively the influence of his aseptic procedures on medical practice, but neither general works nor studies dealing USA.

* K. Codell Carter, PhD, Professor of Philosophy, Brigham Young University, Provo, Utah 84602,

${ }^{1}$ August Theodor Stamm, 'Ueber die Vernichtungsmöglichkeit des epidemischen Puerperalfiebers', Wien. med.-Halle, 1864: 5. The essay appears in short segments between pages 157 and 477; the quotation is taken from p. 477. Parts of this paper are based on K. Codell Carter, 'Semmelweis's possible influence on Karl Mayrhofer and on those who subsequently developed nineteenth century etiological theories'. Orvo. Köz., 1982, 97-99.

${ }^{2}$ Owsei Temkin, 'Health and disease', reprinted in The double face of Janus, Baltimore and London, Johns Hopkins University Press, 1977, p. 436; K. Codell Carter, 'The germ theory, beriberi, and the deficiency theory of disease', Med. Hist., 1977, 21: 119-136; idem, 'Germ theory, hysteria, and Freud's early work in psychopathology', ibid., 1980, 24: 259-274.

${ }^{3} \mathrm{~K}$. Codell Carter, 'Semmelweis and his predecessors', ibid., 1981, 25: 57-72.

'In particular, there is no evidence that Joseph Skoda or Karl Rokitansky ever accepted Semmelweis's aetiological approach (ibid., pp. 65-69). I have given additional attention to this issue in the translator's introduction in Ignaz Semmelweis, The aetiology, concept and prophylaxis of childbed fever, Madison, University of Wisconsin Press, 1983, pp. 32-36, 48-53. 


\section{K. Codell Carter}

specifically with subsequent proponents of his views give careful attention to his possible contributions to medical theory. ${ }^{5}$

In this paper we shall examine one possible line of influence between Semmelweis's theoretical approach and the aetiological investigations that were so central to late nineteenth-century medicine. There is little evidence that subsequent researchers consciously adopted Semmelweis's method. As we shall see, however, it seems very probable that Semmelweis's strategy was influential in a more subtle way.

We shall first contrast briefly some of Semmelweis's opinions about childbed fever with the opinions of one of his chief opponents, Carl Braun. We shall then examine the work of Carl Mayrhofer, who identified certain micro-organisms as the cause of childbed fever, and we shall examine the evidence that Mayrhofer was influenced by Semmelweis's conception of the disease. Finally, we shall consider the relation between Semmelweis's and Mayrhofer's investigations and early research into the aetiology of the infected wound diseases.

\section{I}

Semmelweis's work was first announced by Ferdinand Hebra and Joseph Skoda. These announcements contained no suggestion that every case of childbed fever was due to one common cause. Semmelweis seems first to have made this claim in a lecture on 15 May 1850; in that lecture, and in each of his subsequent publications on the subject, he insisted that every case of the disease was due to the resorption of decaying animal-organic matter. ${ }^{6}$ This claim was certainly false given existing symptomatic and anatomical characterizations of the disease-childbed fever included a range of different disorders without a common necessary cause. Semmelweis's claim required that childbed fever be characterized aetiologically; he may not have fully met this requirement until the publication of his book in 1860 .

The response to Semmelweis's May lecture seems to have depended almost entirely on how seriously one took Semmelweis's claim to have found a universal necessary cause: those who understood Semmelweis's claim, rejected it; other writers ignored it and thought they agreed with Semmelweis because they accepted the chlorine washings. ${ }^{7}$ Between 1850 and 1861 , there is no documentary evidence that anyone in Europe accepted Semmelweis's claim to have found a universal necessary cause for the disease. Yet Semmelweis himself clearly understood that this claim and the new concept of disease which it entailed was the most important difference between himself and his opponents. ${ }^{8}$

\footnotetext{
${ }^{5}$ To take three prominent examples, none of the following considers this aspect of Semmelweis's work: György Gortvay and Imre Zoltán, Semmelweis: his life and work, Budapest, Akadémiai Kiadó, 1968; Erna Lesky, Ignaz Philipp Semmelweis und die Wiener medizinische Schule, Vienna, Hermann Böhlaus, 1964; Herbert Böttger, 'Förderer der Semmelweisschen Lehre', Sudhoffs. Arch. Gesch. Med. Naturw., 1955, 39: 341-362. Lesky briefly discusses some of the theoretical principles underlying Semmelweis's approach in 'Ignaz Philipp Semmelweis: Legende und Historie', Dt. med. Wschr., 1972, 97: 627-632. I have discussed this essay in Semmelweis, op. cit., note 4 above.

${ }^{6}$ Ibid. pp. 29-36.

${ }^{7}$ Ibid.

${ }^{8}$ For example, his essay explaining the difference between his views and those of the English ends with these sentences: "The important difference between my opinion and the opinion of the English physicians consists of this: in every case, without a single exception, I assume only one cause, namely decaying matter, and am convinced of this. The English physicians, while believing that childbed fever can be caused by
} 


\section{Semmelweis, Mayrhofer, and the rise of germ theory}

Until two months before his 1850 lecture, Semmelweis was the assistant in the first obstetrical clinic in Vienna; his chief was Johann Klein, professor of obstetrics at the University of Vienna. Semmelweis was not reappointed as assistant and was unable to obtain any position that would have enabled him to continue his research. In October 1850, he left Vienna and returned to his home in Budapest. ${ }^{9}$

Semmelweis was succeeded as assistant in the first clinic by Carl Braun, who became a prominent Viennese obstetrician and ultimately succeeded to Johann Klein's professorship. In 1855, Braun published an extensive account of childbed fever, which contained a thirty-seven-page discussion of the aetiology of the disease.$^{10}$ Braun listed thirty possible causes of childbed fever. These included conception itself, the general plethora of pregnancy, the shock to the nervous system occasioned by delivery, the pressure of milk secretions, the individuality of the patient, emotional disturbances, mistakes in diet, defective ventilation, chilling, epidemic influences, various inappropriate conditions in maternity hospitals, and cadaverous infection.

Braun ascribed to Semmelweis the view that cadaverous infection was the main, perhaps the only, cause of childbed fever. Hebra and especially Skoda had suggested that Semmelweis was concerned primarily with cadaverous matter, and, indeed, this may have been true in 1847 when Semmelweis began using aseptic procedures. By the 1850 lecture, however, Semmelweis's conception of the disease had changed; he hypothesized that any decaying organic matter (not just cadaverous substances) could cause the disease. While Braun explicitly admitted that cadaverous infection could account for some cases, ${ }^{11}$ he denied that it could have the significance that (on his mistaken interpretation) Semmelweis ascribed to it. Braun cited numerous other writers who had raised similar objections. He also reviewed evidence that Semmelweis's prophylactic aseptic procedures were much less effective than Semmelweis had claimed.

While insisting that childbed fever could result from many unrelated causes, Braun gave particular attention to Jakob Henle's conjecture that infectious diseases may be due to microscopic parasites. Braun suggested that many so-called epidemic cases of childbed fever could be explained by assuming that germs of such parasites were conveyed through the air into the open wounds of maternity patients. This notion fitted well with the old idea that childbed fever was the result of miasmatic influences that affected predisposed persons in the maternity wards. As Braun himself observed, this was simply a new materialistic interpretation of the old conception of a miasma. In this and other respects, Braun's view was very similar to the position taken by Gottfried Eisenmann twenty years earlier. ${ }^{12}$ Braun cited various other

\footnotetext{
decaying matter, recognize in addition all the old epidemic and endemic causes that have been believed to play a role in the origin of the disease." The essay is reprinted in Tiberius von Györy, Semmelweis' gesammelte Werke, Jena, Fischer, 1905, see p. 95.

${ }^{9}$ I discussed some attempts to explain Semmelweis's departure from Vienna in Semmelweis, op. cit., note 4 above, p. 23.

${ }^{10}$ Carl Braun, 'Zur Lehre und Behandlung der Puerperalprocesse und ihrer Beziehungen zu einigen zymotischen Krankheiten', in Baptist Johann Chiari, Carl Braun, and Joseph Späth, Klinik der Geburtshilfe und Gynaekologie, Erlangen, Ferdinand Enke, 1855, pp. 450-487.

11 Ibid., p. 484.

${ }^{12}$ Gottfried Eisenmann, Die Wund-Fieber und die Kindbett-Fieber, Erlangen, J. J. Palm and Ernst Enke, 1837.
} 


\section{K. Codell Carter}

individuals whose work could be interpreted as supporting this suggestion.

Two years later, in his textbook on obstetrics, Braun again discussed puerperal fever. ${ }^{13}$ This discussion was similar to his earlier one, but there were some changes. While Braun still rejected the hypothesis that cadaverous infection accounted for all cases of the disease, he omitted all specific references to Semmelweis. He also gave increased emphasis to the possibility that epidemic childbed fever could be due to germs from micro-organisms that were conveyed through the air. He hypothesized that improved ventilation would reduce the disease. Over the next few years, publications by other obstetricians supported Braun's view that the air in maternity wards was important in the spread of the disease. ${ }^{14}$

In the fall of 1860, Semmelweis's main book, Die Aetiologie, der Begriff, und die Prophylaxis des Kindbettfiebers, appeared..$^{15}$ In this book, as in his 1850 lecture, Semmelweis insisted that every case of childbed fever was due to the absorption of decaying animal-organic matter. He provided aetiological characterizations of childbed fever and of pyaemia ${ }^{16}$-probably the first in the history of either disease. Semmelweis insisted, as he had earlier, that in almost every case, the decaying matter that caused childbed fever was conveyed by the contaminated hands of medical personnel or by unclean medical instruments. Semmelweis also discussed Braun's account of childbed fever, ${ }^{17}$ and he ridiculed the old miasmatic conception with which it was associated. However, Semmelweis did not give adequate attention to Braun's ideas. For example, he categorically dismissed that part of Braun's account which included the suggestion that childbed fever could be caused by germs from microscopic parasites. ${ }^{18}$

The initial response to Semmelweis's book seems to have been very much like the reaction to his 1850 lecture: everyone admitted that childbed fever could be caused by decaying organic matter and that chlorine washings were useful in controlling these cases. However, with the exception of Wilhelm Lange, everyone denied that every case of childbed fever could be explained in this way. ${ }^{19}$ Most obstetricians still

\footnotetext{
${ }^{13}$ Carl Braun, Lehrbuch der Geburtshilfe, Vienna, Braumüller, 1857, pp. 913-930.

${ }^{14}$ Among the most influential of these were Carl Hecker and Ludwig Buhl, Klinik der Geburtskunde, Leipzig, Engelmann, 1861. Like Braun, they regarded childbed fever as a zymotic disease and held that its epidemic appearance in maternity wards was usually due to the spread of germs through the air.

${ }^{15}$ Ignaz Philipp Semmelweis, Die Aetiologie, der Begriff und die Prophylaxis des Kindbettfiebers, Pest, Vienna, and Leipzig, Hartleben, 1861. The publication date of the Aetiology is given as 1861, but it actually appeared in October 1860 . Gortvay and Zoltán, op. cit., note 5 above, p. 132.

${ }^{16}$ Semmelweis, op. cit., note 15 above, pp. $102,106$.

${ }^{17}$ Ibid., pp. 484-593.

${ }^{18}$ Semmelweis said that Braun's account "is a horrible example of the monstrosities that occur when one compiles without understanding. We leave this chaos unexplored." (Ibid., p. 532).

${ }^{19}$ Carl S. F. Crede (Mschr. Geburtsk. Frauenkr., 1861, 18: 406f) and August Breisky (Vrtljschrft. prakt. Heilk., Literärischer Anzeiger, 1861, 18: II: 1-13) both took this position in reviewing the Aetiologie. Hecker and Buhl (op. cit., note 14 above, p. 226) said the same thing. By contrast, in 1861, Wilhelm Lange of Heidelberg publicly declared himself to be an adherent of Semmelweis's doctrines. This occurred in the annual meeting of the Gesellschaft Deutscher Naturforscher und Aerzte, held in Speier in 1861. The most detailed report of the meeting is in the Mschr. Geburtsk. Frauenkr., 1861, 18: 375-382. Three years later, several respected physicians, including Lange, were asked to submit formal responses to a series of questions intended to guide the construction of a new maternity hospital in Prague. Lange enthusiastically endorsed Semmelweis's views. Joseph Skoda, Karl Rokitansky, and Johann Oppolzer, who together submitted another set of responses, did not mention Semmelweis and, in harmony with Carl Braun, attributed epidemic childbed fever to miasmata ('Puerperalfieber und Gebärhäuser', Wien. med.-Halle, 1864, 5: 113-115, 125f). Yet Skoda and Rokitansky are invariably mentioned as Semmelweis's supporters.
} 
believed that puerperal fever could be caused in many unrelated ways, ${ }^{20}$ and many preferred Braun's view that the disease was usually spread through the air to Semmelweis's opinion that contaminated hands presented the greatest danger.

By 1862, researchers were beginning to identify micro-organisms in the female genitals, and several had speculated that such organisms could cause childbed fever. ${ }^{21}$ These results were construed as supporting Braun's conception of the disease.

This was the situation when, in 1862, Carl Mayrhofer was appointed as an assistant in the first maternity clinic.

\section{II}

Carl Mayrhofer was born on 2 June 1837 in Steyr, Austria;22 his father was a physician. He attended the Kremsmunster Gymnasium where he was recognized as unusually bright. ${ }^{23}$ Mayrhofer studied medicine at the University of Vienna, and, in the course of his studies, he worked with Ferdinand Hebra, who had published the first report of Semmelweis's findings and who remained Semmelweis's friend. ${ }^{24}$ Mayrhofer was awarded an MD degree in 1860. After further study of surgery, in 1862, he was appointed second assistant to Carl Braun in the Viennese first maternity clinic. Shortly afterwards, Braun urged him to investigate the aetiology of childbed fever. "He [Braun] encouraged me to the highest degree; he said he had such an interest in resolving the matter that he would gladly cover the costs of the work from his own resources." ${ }^{25}$ In the next year, 1863, Mayrhofer published his initial results. ${ }^{26} \mathrm{He}$ also delivered a lecture before the Gesellschaft der Aerzte in Wien, ${ }^{27}$ and this lecture was also published. ${ }^{28}$ In 1864 , Mayrhofer gave an additional

\footnotetext{
${ }^{20}$ This is clear in each of the first three references in the preceding note and in the response to Lange's paper in the fourth reference. See also Eduard von Siebold, 'Betrachtungen über das Kindbettfieber', Mschr. Geburtsk. Frauenkr., 1861, 17: 335-357, 401-417; 18: 19-39; pp. 338-357.

${ }^{21}$ One early examination of micro-organisms in the female genital tract was Louis Mayer's 'Ueber die pflanzlichen Parasiten der weiblichen Sexualorgane in ihrer praktischen Bedeutung', ibid., 1862, 20: 216. Many writers regarded childbed fever as a zymotic disease. See, for example, Siebold, op. cit., note 20 above, p. 340, Hecker and Buhl, op. cit., note 14 above, p. 220, and Braun, op. cit., note 10 above, p. 424. There were several discussions of the possibility that the disease was due to microscopic parasites, e.g. Hoffmann, 'Zur Theorie des Kindbettfiebers', Aerztl. Intell.-bl., 1861, 8: 30-35; and V.-A.-A. Dumontpallier, 'De l'infection purulente puerpérale', L'un. méd. Paris, 1862, 39: 197-203, 211-218, 229-236, 248-254, 345-349, 356-361, 394-399. Attempts to identify parasites in the blood of victims were unsuccessful. See, for example, Eduard Martin, 'Ueber eine im Winter 1859-1860 beobachtete Epidemie puerperaler Colpitis und Endometritis', Mschr. Geburtsk. Frauenkr., 1860, 16: 161-175, p. 162.

${ }^{22}$ Not in the province of Styria (Steiermark) as "Steyr" is mistakenly translated in the English edition of Erna Lesky's The Vienna medical school of the nineteenth century, Baltimore and London, Johns Hopkins University Press, 1976, p. 190.

${ }^{23}$ This is from an obituary signed "Ch." that appeared in the Wien. med. Presse, 1882, 23: cols. 778-779, c. 778 .

${ }^{24}$ I. Fischer, Geschichte der Geburtshilfe in Wien, Vienna and Leipzig, Vogel, 1909, p. 352.

${ }^{25}$ Carl Mayrhofer, 'Vorläufige Mitteilung über das Vorkommen von Vibrionen bei Wöchnerinnen und deren allfällige Bedeutung für Puerperalerkrankungen', Z. k. k. Ges. Aertzte Wien, 1863, 19: 17-20, p. 17.

${ }^{26}$ Ibid.

${ }^{27}$ The lecture was reported in Allg. wien. med. Z., 1863, 8: 63, and in Wien. med.-Halle, 1863, 4: 90f.

${ }^{28}$ Carl Mayrhofer, 'Untersuchungen über Aetiologie der Puerperalprocesse', Z. k. k. Ges. Aertze Wien, 1863, 19: $28-42$.
} 


\section{K. Codell Carter}

lecture summarizing his findings, ${ }^{29}$ which was published in the following year. ${ }^{30}$

In these papers, Mayrhofer referred to Jakob Henle's conjecture that many infectious diseases were caused by micro-organisms,${ }^{31}$ and he cited investigations by Bassi and Pasteur showing that muscardine was caused by parasitic organisms. ${ }^{32}$ It was commonly believed that fermentation and organic decomposition were closely related processes, and Mayrhofer was familiar with Pasteur's conclusion that fermentation was always due to living ferments. ${ }^{33}$ Because the uterus seemed to be the most common focus of childbed fever, he began looking for living fermenting agents in uterine discharges from puerperal fever victims. At first, Mayrhofer found nothing because the only microscope available in the Viennese obstetrical clinic was not powerful enough to make micro-organisms clearly visible. ${ }^{34} \mathrm{~A}$ short time later, however, through Braun's efforts, ${ }^{35}$ a new instrument was procured and Mayrhofer's search was successful. He ultimately observed and described various organisms in the uterine discharges of more than one hundred living and dead victims. These organisms differed in size and shape, in their motility, in their reaction to acidic media, and in their capacity to ferment liquids. Following what was common (but not universal) usage, Mayrhofer referred to all these organisms as "vibrions" ${ }^{36}$

Among the different organisms that he observed, Mayrhofer found one form to be most abundant and to be regularly present in discharges from puerperal fever victims. These vibrions were of relatively constant dimensions, motile, incapable of living in acids, and they fermented various sugar solutions. Mayrhofer sometimes found the same organisms in healthy patients, but never until the fifth day after delivery. ${ }^{37} \mathrm{He}$ hypothesized that the normally acidic vaginal secretions of healthy patients helped protect them from invasion by the vibrions. ${ }^{38} \mathrm{He}$ conducted animal experiments to decide whether the vibrions actually caused childbed fever or whether they simply found, in the diseased patient, a suitable medium in which to develop. ${ }^{39}$ Mayrhofer injected fluids containing vibrions into the genitals of newlydelivered rabbits; the rabbits invariably became diseased and died, and postmortem examination revealed morbid changes similar to those in victims of puerperal fever. ${ }^{40}$ $\mathrm{He}$ also cultivated vibrions in a sugar and ammonia solution. After filtering the

${ }^{29}$ The lecture was reported in Allg. wien. med. Z., 1864, 9: 181f, 190; Wien. med.-Halle, 1864, 5: 261f; and in Z. k. k. Ges. Aerzte Wien, 1864, 20: 249-255. There were brief notices in other Viennese periodicals. 134.

30 'Zur Frage nach der Aetiologie der Puerperalprocesse', Mschr. Geburtsk. Frauenkr., 1865, 25: 112-

${ }^{31}$ Mayrhofer, op. cit., note 25 above, p. $19 \mathrm{fn}$.

${ }^{32}$ Ibid., p. 18.

${ }^{33}$ Mayrhofer, op. cit., note 30 above, p. 121.

${ }^{34}$ Mayrhofer, op. cit., note 25 above, p. 18.

${ }^{35}$ Ibid.

${ }^{36}$ Mayrhofer discusses his use of the term at op. cit., note 30 above, pp. $117 \mathrm{f}$.

${ }^{37}$ Mayrhofer, op. cit., note 28 above, p. 38. This claim is of some interest since it was the main focus of the few persons who challenged his work.

${ }^{38}$ Mayrhofer, op. cit., note 30 above, p. 128.

${ }^{39}$ Mayrhofer, op. cit., note 28 above, p. 38. The possibility that, instead of causing diseases, microorganisms simply flourished in diseased tissues as harmless saprophites continued to receive attention through the next several decades. A good part of Koch's early papers on anthrax and tuberculosis were devoted to resolving this question. Koch's arguments focused on animal experiments that were basically similar to Mayrhofer's.

${ }^{40}$ Mayrhofer, op. cit., note 25 above, p. 19; note 28 above, pp. 38f. Mayrhofer admitted that there were 
solution to isolate the vibrions from other decomposition products, he injected them into rabbits. This produced the same results. ${ }^{41}$ From these experiments and his other evidence, Mayrhofer concluded that puerperal fever was a "fermentation disease" in which tissues decomposed under the influence of the living vibrions. ${ }^{42}$

It seems likely that Mayrhofer's work was based directly on Braun's conception of childbed fever. In any case, his results were completely compatible with Braun's views. Perhaps this contributed to the favourable reception that Mayrhofer's work initially received in Vienna..$^{43}$ However, Mayrhofer did not continue to enjoy general support. Looking back a few years later, one contemporary physician observed, "If one says that Mayrhofer's work attracted universal attention, this should not be understood in a positive sense only. Such an energetic talent, which transcends the mass of mediocrity, often finds itself all too vulnerable to misfortune." in spite of his initial success, Mayrhofer's investigations were generally neglected and undervalued. ${ }^{45}$ After 1865 , Mayrhofer continued to publish, but in only one brief passage did he return to the topic of childbed fever. ${ }^{46}$

In August 1865, while Mayrhofer was still Braun's assistant, Semmelweis died in an insane asylum in Lower Austria, where he had been taken two weeks before; his body was autopsied in the Vienna Allgemeines Krankenhaus, and there were notices of his death in Viennese medical periodicals. ${ }^{47}$

After eight years as assistant in the first clinic, in 1870, Mayrhofer was appointed privat-docent of obstetrics and women's diseases; a few years later, he was appointed an extraordinary professor of the same speciality. At first, he achieved considerable success in his private practice in Vienna; however, during the 1870s, he experienced various kinds of misfortune. While still in the first clinic, he suffered from lymphangitis and haematosis; these health problems continued as he began private practice. Two of his children died. He also met frustrations in his profession. "The undeserved disappointments that Mayrhofer continued to experience drove him to morphine and maimed the life of this otherwise energetic individual." ${ }^{\prime 48}$ Mayrhofer

\footnotetext{
differences between puerperal fever victims and the test animals and that the experiments were not completely conclusive (Z. k. k. Ges. Aerzte Wien, 1864, 20: 252f).

${ }^{41}$ Mayrhofer, op. cit., note 28 above, p. 39.

${ }^{42}$ Mayrhofer, op. cit., note 27 above, p. 63.

${ }^{43}$ For example, the report of Mayrhofer's initial paper in Allg. Wien. med. Z., 1863, 8: 63, concludes "the lecture generated very great interest, and the audience listened with attentive suspense". The report in Z. k. k. Ges. Aerzte Wien, 1863, 19: 79, contains a similar remark. Apparently, the comments made after Mayrhofer's lecture were also favourable.

${ }^{44}$ This is from an obituary signed "r." that appeared in the Wien. med. Bl., 1882, 5: col. 725.

${ }^{45}$ Several persons who mentioned Mayrhofer made this point. For example, ibid., and Fischer, op. cit., note 24 above, p. 353.

${ }^{46}$ For a list of Mayrhofer's publications, see ibid., p. 353f. Mayrhofer briefly discussed puerperal fever in a work published just at the end of his life, which was included in Theodor Billroth's multi-volumed Handbuch der allgemeinen und speciellen Chirurgie. Mayrhofer's contribution was Sterilität des Weibes, Entwicklungsfehler und Entzündungen der Gebärmutter, Stuttgart, Ferdinand Enke, 1882. Regarding childbed fever, Mayrhofer observed (p. 143) that he would "today, neither add to nor subtract from" what he had earlier written. He then responded briefly to David Haussmann's criticism of his work. (Haussmann is discussed in the next section of this paper.)

${ }^{47}$ For a list of these notices see Frank P. Murphy, 'Ignaz Philipp Semmelweis (1818-1865), an annotated bibliography', Bull. Hist. Med., 1946, 20: 653-707, p. 672.

${ }^{48}$ Op. cit., note 23 above, c. 779.
} 


\section{K. Codell Carter}

moved to Russia in 1878; one contemporary ascribed the move to his continuing misfortune and to "a loss of interest in the affairs of practical life". ${ }^{49}$ After a successful beginning in Tiflis (now Tbilisi), he moved to St Petersburg, where he experienced further disappointments and frustrations. In 1881, he moved to Franzensbad (now Frantiskovy in western Czechoslovakia). During the following winter, he became seriously ill. He died on 3 June 1882, the day following his forty-fifth birthday. A contemporary noted that "everyone who was close to Mayrhofer recognized that for him, death was a salvation".50

\section{III}

In an obituary, one writer observed that in some respects Mayrhofer's "professional life was reminiscent of the tragic experiences of another gynaecologist from the Vienna school, the genius Semmelweis". ${ }^{51}$ In his Geschichte der Geburtshilfe in Wien, I. Fischer noted that Mayrhofer's "investigations of the germ content of lochial secretion and of the aetiology of puerperal fever, which followed Pasteur's work and preceded Lister's discoveries, together with the circumstance that, precisely in Vienna, he was never properly recognized, earned him the title of a second Semmelweis". ${ }^{52}$ Erna Lesky also mentioned Mayrhofer in her monumental book, The Vienna Medical School of the nineteenth century. She pointed out that, "with his investigations of the germ content of the lochia, Mayrhofer took up the problem of puerperal diseases at the point at which Semmelweis had abandoned it". ${ }^{53}$ Lesky also referred to Mayrhofer as "the second Semmelweis". ${ }^{54}$ But neither Fischer nor Lesky suggested that Mayrhofer was directly influenced by Semmelweis. Indeed, so far, no one seems to have seen more than an accidental connexion between them. Mayrhofer is not cited in Frank P. Murphy's extensive bibliography of publications relating to Semmelweis ${ }^{55}$ nor in Böttger's discussion of subsequent proponents of Semmelweis's teachings. ${ }^{58}$ Semmelweis's major biographers do not suggest that he influenced Mayrhofer; in fact, of the many individuals who have written on Semmelweis in this century, apparently only Lesky, Fischer, and Schurer von Waldheim have even mentioned Mayrhofer ${ }^{57}$ No doubt this is partly because Mayrhofer himself did not mention Semmelweis, and the evidence of a direct

\footnotetext{
${ }^{49}$ Ibid.

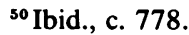

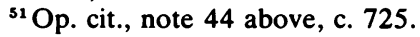

${ }^{52}$ Fischer, op. cit., note 24 above, p. 352.

${ }^{53}$ Lesky, op. cit., note 22 above, p. 190.

${ }^{54}$ Ibid., p. 189.

${ }^{55}$ Murphy, op. cit., note 47 above.

${ }^{56}$ Böttger, op. cit., note 5 above.

${ }^{57}$ Fritz Schurer von Waldheim, Ignaz Philipp Semmelweis. Sein Leben und Wirken, Vienna and Leipzig, Hartleben, 1905. Here, Mayrhofer is mentioned four times: the first (p. 203) includes a brief summary of his work; the second (p. 208) and third (p. 228) are in passages quoted from Joseph Späth and Gustav Veit in which Mayrhofer and Semmelweis are associated-these passages are discussed below. In the fourth passage, (p. 230), Waldheim cites David Haussmann as having refuted Mayrhofer by showing that lochial secretions from healthy patients sometimes contained vibrions-Haussmann's work is also discussed below. Thus, the only suggestion that Mayrhofer's work was related to Semmelweis's was in passages that Waldheim quoted from others; he himself made no such suggestion and he did not explore further the remarks by Späth and Veit.
} 
connexion is, therefore, largely circumstantial. Yet, if one considers the evidence, it seems very likely that by 1864 , when he delivered his final lecture on childbed fever, Mayrhofer recognized that Semmelweis's conception was fundamentally correct and that it supported and was supported by his own investigations.

During the early sixties, Semmelweis was frequently mentioned and discussed in European medical literature. There has been a long-standing opinion that Semmelweis and his work were generally ignored through the middle and late decades of the nineteenth century. ${ }^{58}$ Various writers have shown that this opinion is inaccurate. ${ }^{59}$ For our purposes, it is sufficient to consider the four years from the beginning of 1861, the year before Mayrhofer entered the first clinic, until the end of 1864 , by which time he had probably completed his final publication on childbed fever. Murphy's bibliography, which "represents a fair cross-section of the literature on Semmelweis and his doctrines", ${ }^{60}$ includes forty-four items from these years. Twelve were publications by Semmelweis himself. Another six were written in Hungarian and, therefore, probably inaccessible in most European medical circles. Five more, although directly relevant to Semmelweis's work, did not mention him explicitly. This leaves twenty-six publications, all generally accessible to European physicians, in which Semmelweis was mentioned or discussed. And Murphy's list is by no means exhaustive; in these four years, there were several other similar publications that might have been included, ${ }^{61}$ and more than a dozen abstracts or reviews mentioned Semmelweis and his work. Several of these items appeared in widely read periodicals and were written by prominent researchers. Thus, in the years in which Mayrhofer was beginning and carrying out his research, Semmelweis was mentioned or discussed in an average of about ten medical publications each year. Semmelweis's work was cited by some of Braun's students in the first clinic. ${ }^{62}$

\footnotetext{
${ }^{58}$ This view was certainly reinforced by comments by August Hirsch and Joseph Lister. In the second edition of his Handbuch der historisch-geographischen Pathologie (Stuttgart, Ferdinand Enke, 1883, vol. 2, p. 320), Hirsch observed, "I take credit for having, in the first edition of this work [1862-1864], written in Semmelweis's defence and for having directed the attention of the profession in Germany to his writings. At that time his work was generally unknown." In a letter explaining his relation to Semmelweis, Lister described a visit to Budapest in the mid-1880s. He recalled that he was warmly greeted by colleagues and students, but wrote that "on that occasion the name of Semmelweis was not mentioned, he seems to have been forgotten by his native country to the same extent as by everybody else throughout the world". (Quoted in Gortvay and Zoltán, op. cit., note 5 above, pp. 220f.) A careful examination of the literature shows that both observations are false.

${ }^{59}$ See, for example, Vilmos Manninger, Der Entwickelungsgang der Antiseptik und Aseptik, Breslau, Kerns, 1904, pp. 74-78; and Böttger, op. cit., note 5 above.

${ }^{60}$ Murphy, op. cit., note 47 above, pp. 665-671.

${ }^{61}$ For example, Semmelweis was mentioned or discussed in Hecker and Buhl, op. cit., note 14 above, pp. 224f; Gustav Schimmer, 'Todesfälle in Folge von Puerperal-Ereignissen', Wien. med.-Halle, 1863, 4: 81f, 89f, 99f, p. 81; Rudolf Maier, 'Pathologisch-anatomische Notizen zum Puerperalfiever', Virchows Arch. path. Anat. Physiol., 1864, 29: 526-558, p. 528; and Stamm, op. cit., note 1 above, pp. 166, 205, 261, 269, 333, 373, 400, 477. These publications, and doubtless several others, are not included in Murphy's list.

${ }^{62}$ In 1864, August Theodor Stamm, one of Braun's students in the first clinic, mentioned Semmelweis favourably in two papers: ibid; and 'Ueber Grösse und Einrichtung von Gebäranstalten, resp. über Vernichtungsmöglichkeit des epidemischen Puerperalfiebers', Gesell. Dt. Naturforscher und Aerzte in Giessen 1864, Giessen, Keller, 1865, pp. 254-256. Stamm reported that it was at his suggestion that the windows were opened in the first clinic to improve ventilation and that the mortality rate declined thereafter. Stamm observed that world medical literature had confirmed Semmelweis's claim that childbed fever could be spread by unclean hands, but, in harmony with Braun, Stamm himself believed that adequate ventilation was even more important.
} 


\section{K. Codell Carter}

Given all of this, it is inconceivable that Mayrhofer, a brilliant research-oriented obstetrician who was particularly noted for his knowledge of medical literature, ${ }^{63}$ could have remained ignorant of Semmelweis's work.

While Mayrhofer was working in the first clinic, the second clinic, which was for student midwives, was supervised by Joseph Späth. Späth was a prominent obstetrician in Vienna and, like all his Viennese colleagues, he had originally opposed Semmelweis's views on childbed fever. In 1863 and 1864, Späth published several statistical and historical studies of the incidence of childbed fever among different groups of patients. ${ }^{64}$ These studies repeated much of the evidence on which Semmelweis had based his own account. For the most part, however, Späth seems to have accumulated this evidence independently from Semmelweis. In the early papers, he cited Semmelweis, but only inconsequentially, and he did not agree with (and probably did not understand) Semmelweis's position. ${ }^{65}$ However, the result of these studies seems to have been that by the beginning of 1864 , Späth had become converted to Semmelweis's conception of the disease. In an 1864 paper, Späth noted that, whatever anyone might say, every obstetrician now believed that Semmelweis was correct, and he suggested that even Braun's attempt to control childbed fever by installing expensive ventilation equipment was ultimately based on an awareness that Semmelweis was right. ${ }^{86} \mathrm{He}$ also noted that, "even Mayrhofer's theory, if it turns out to be correct, can only be regarded as a further confirmation of Semmelweis's view, because in that theory the vibrions which originate in decomposed animal matter are taken as the infective agents." ${ }^{87}$ Thus, by 1864, Mayrhofer's results had been explicitly associated with Semmelweis's theory.

Mayrhofer's first two publications contain almost nothing to suggest that he was directly influenced by Semmelweis, and his work in the first clinic was probably based directly on Braun's views. However, Mayrhofer's third paper, which was much more comprehensive than either of the first two, was closer to Semmelweis than to Braun. Mayrhofer occasionally used language that was reminiscent of Semmelweis. ${ }^{68} \mathrm{He}$ knew and cited facts that Semmelweis had used but that Braun had challenged. ${ }^{69}$ But

${ }^{63}$ Op. cit., note 23 above, c. 779.

${ }^{64}$ Joseph Späth, 'Ueber die Sanitäts-Verhältnisse der Wöcherinnen an der Gebärklinik für Hebammen in Wien vom October 1861 bis Jänner 1863', Med. Jb., 1863, 19:10-27; idem, 'Historische Ueberblicke der Vorkommnisse im Wiener Gebärhause seit 1784 bis 1863, mit besonderer Berücksichtigung der Puerperal-Erkrankungen', Wien. med. Wschr., 1864, 14: cols. 164-167; idem, 'Rückblicke auf die letzten dreissig Jahre des Wiener Gebärhauses', Z. k. k. Ges. Aerzte Wien, 1864, 20: 64-66; and (the published version of the preceding paper which apparently differs from it in certain respects) 'Statistiche und historische Rückblicke auf die Vorkommnisse des Wiener Gebärhauses während der letzten dreissig Jahre mit besonderer Berücksichtigung der Puerperal-Erkrankungen', Med. Jb., 1864, 20: 145-164.

${ }^{65}$ In 1861, in a notice of the publication of the Aetiologie, Späth observed, incorrectly, that Semmelweis's doctrine had not changed since the original 1847 announcement (Med. Jb., 1861, 17: 158). In the last of the papers cited in the preceding footnote, Späth explicitly denied this and stressed the change in Semmelweis's position (p. 161). Perhaps his sarcastic treatment of Semmelweis in the first paper cited in note 64 above indicates that he still held his earlier mistaken view and that he did not yet understand Semmelweis's true position.

${ }^{86}$ Späth, op. cit., note 64 above (last paper cited), pp. 160-162.

${ }^{87}$ Ibid., p. 162.

${ }^{68}$ For example, both Mayrhofer (op. cit., note 30 above, p. 134) and Semmelweis (op. cit., note 15 above, p. 212) asserted that the epidemic theory of childbed fever attempted to explain the unknown by the unknown.

${ }^{69}$ Mayrhofer used the facts that first births and difficult deliveries were more dangerous than ordinary 
there were two particularly important aspects of Mayrhofer's account that revealed his change of allegiance. First, in the 1865 paper, Mayrhofer observed that, while the harmful material influence that caused puerperal fever could be conveyed through the air, infection was usually due to the examining finger. ${ }^{70}$ As early as 1855 , Braun suggested that germs, conveyed through the air, were an important cause of childbed fever. ${ }^{71}$ In two 1864 papers, Braun identified proper ventilation as the most important prophylaxis against the disease. ${ }^{72}$ In the same year, under Braun's leadership, an expensive new ventilation system was installed in the Viennese maternity clinic. In 1864, one of Braun's students, August Theodor Stamm, also presented papers in which he argued that improved ventilation, rather than the use of chlorine washings, was responsible for improved mortality rates in the first clinic. ${ }^{73}$ Initially, Mayrhofer had agreed with Braun; one account of Mayrhofer's first lecture clearly indicated that he believed that vibrion germs were usually conveyed through the air. ${ }^{74}$ However, by 1865 , Mayrhofer had given up attempting to explain how vibrions could be conveyed through the air and had concluded, as Semmelweis had before him, that infection was usually due to the contaminated hands of medical examiners. ${ }^{75}$ Second, in 1865 for the first time, Mayrhofer claimed to have identified a universal necessary cause of all instances of childbed fever. Like Semmelweis, he used this cause to characterize the disease and to classify specific cases of illness. ${ }^{76}$ Carl Mayrhofer and Wilhelm Lange seem to have been the only two physicians in Europe who had accepted the possibility that every case of childbed fever could be ascribed to one single cause. In a book published in 1864, for example, Gustav Braun, Carl Braun's brother and former student, continued to ascribe the disease to various unrelated causes. ${ }^{77}$ Given these subtle but strategic changes, it seems very likely that by 1865 , Mayrhofer had become a convert to the Semmelweis doctrine.

There were, of course, important differences between Mayrhofer and

deliveries and that so-called street deliveries were less dangerous than deliveries in the hospital. Op. cit., note 30 above, pp. 125, 128. Späth emphasized these facts in his papers, but, given Späth's endorsement of Semmelweis, the possibility that Mayrhofer was citing Späth rather than Semmelweis himself is hardly telling against my position. Braun minimized the significance of these facts (op. cit., note 10 above, p. 475).

${ }^{70}$ Mayrhofer, op. cit., note 30 above, p. 125.

${ }^{71}$ Braun, op. cit., note 10 above, pp. 481-483.

${ }_{72}$ Carl Braun, 'Ueber Luftwechsel und Puerperalkrankheiten', Wien. med. Wschr., 1864, 14: cols. 257-259; idem, 'Ueber Luftwechsel, den neuen Ventilations-Bau mit Benützung der natürlichen Temperaturdifferenzen und Luftströmung', Med. Jb., 1864, 20: 165-208. In the second, Braun wrote, "I hold defective ventilation ... to be a significant cause of the frequent illness of puerpera and as the most important factor in the spread of puerperal fever" (p. 205).

${ }^{73}$ Stamm, op. cit., notes 1 and 62 above.

${ }^{74}$ According to the Wien. med.-Halle report of his 1863 lecture (op. cit., note 27 above, p. 90), Mayrhofer said that since vibrion germs occur in all air and especially in impure air, and since they then breed in decaying matter, when, at certain times, the air is especially rich in vibrion germs, puerperal disease can occur epidemically.

${ }_{75}$ A. C. G. Veit, 'Uber die in der geburtshilflichen Klinik in Bonn im Sommer 1864 und 1864-65 aufgetretenen puerperalen Erkrankungen', Mschr. Geburtsk. Frauenkr., 1865, 25: 127-155, 161-208, p. 196. Veit also observed that the improved mortality rate in the Viennese first clinic was due to Späth's sanitation measures rather than to improved ventilation as Braun and Stamm had maintained.

${ }^{76}$ Mayrhofer, op. cit., note 30 above, pp. 117, 132, 134. In the last two passages, Mayrhofer uses identification of vibrions as the basis for definitive diagnosis of the disease.

${ }^{n}$ Gustav August Braun, Compendium der Geburtshilfe, Vienna, Braumüller, 1864, pp. 305, 308, 314. 


\section{K. Codell Carter}

Semmelweis. Semmelweis showed no interest in the possible aetiological significance of micro-organisms. Semmelweis also believed that childbed fever always involved the decomposition of the victim's blood. Like most of his contemporaries, he probably believed that such decomposition could occur without specific morbid alterations in the uterus and that, in such cases, the disease could take the form of a general fever ${ }^{78}$ Mayrhofer doubted that the disease could occur as a general fever without morbid alterations in the uterus. He reported that he always found local disease to precede general fever. ${ }^{79}$ Mayrhofer believed that the disease was essentially fermentation induced in the uterus under the influence of vibrions; implication of the blood was incidental.

In spite of these differences, it seems obvious, and, as we shall see, it also seemed obvious to Mayrhofer's contemporaries and successors, that Mayrhofer and Semmelweis were in fundamental agreement. One likely interpretation is that Mayrhofer became converted to Semmelweis's position some time after his first two papers were written. Perhaps this occurred in 1864, because of Späth's recognition that Mayrhofer's results could best be understood given Semmelweis's basic theoretical position. Perhaps Mayrhofer accepted Semmelweis's commitment to a universal necessary cause because, in fact, he found vibrions in every victim of childbed fever. In any case, if Mayrhofer disagreed with Späth's characterization of his work, he could have responded either in his 1864 lecture or in his subsequent publication. That he did not reject the association must be interpreted as a tacit acknowledgement that his work was, in fact, essentially related to Semmelweis's investigations.

Why, then, did Mayrhofer never mention Semmelweis? There is an obvious explanation. As Mayrhofer's chief and as professor of obstetrics in Vienna, Carl Braun held Mayrhofer's destiny in his hands. Braun was among Semmelweis's bitterest rivals and antagonists; throughout his life he remained intransigently opposed to the Semmelweis doctrine ${ }^{80}$ Other writers referred to the unusual bitterness between advocates of the opposing theories of childbed fever. ${ }^{81}$ The

\footnotetext{
${ }^{78}$ For example, Semmelweis, op. cit., note 4 above, p. 9.

${ }^{79}$ Although he admitted that he could diagnose local disease only because, in addition to conventional techniques, he used the presence of vibrions as a criterion for illness. Mayrhofer, op. cit., note 30 above, $p$. 132. In this respect, Mayrhofer was in the minority. "The overwhelming majority of recent voices speak decisively in favour of a universal disease and regard localization as incidental." Friedrich Kehrer ("Zur Behandlung des Kindbettfiebers', Mschr. Geburtsk. Frauenkr., 1861, 18: 209-223, p. 212) lists twelve authorities (including both Braun and Semmelweis) who admitted that the disease need not be localized.

${ }^{80}$ In the second edition of his Lehrbuch der gesammten Gynaekologie (Vienna, Braumüller), published in 1881, Braun no longer listed a plurality of unrelated causes. However, the one causal explanation that he provided was similar to the one he had favoured twenty years earlier-he still insisted that infection usually occurred through the air. He denied the aetiological significance of bacteria, and held, instead, that the disease was due to toxic dried vegetable organisms conveyed through the air. He pointed out that this conception was a new interpretation of the miasma theory (pp. 873-879). In this edition, both Semmelweis and Mayrhofer were cited in connexion with the infectious theory that Braun was rejecting.

${ }^{81}$ In 1863, Späth used up the first four pages of a seventeen-page paper on childbed fever trying to convince his colleagues that, however much they might disagree in their interpretations of childbed fever, it should still be possible for them to remain friends (Späth, op. cit., note 64 above, pp. 10-13). Part of the bitterness was certainly due to Semmelweis's offensive personal attacks. Perhaps this hostility explains why Semmelweis seems never to have been mentioned in discussions of Mayrhofer's or Späth's papers. This is particularly remarkable given that both Späth and Josef Skoda, who had also been associated with Semmelweis's work, were present at the discussion of Mayrhofer's papers and were reported as having
} 


\section{Semmelweis, Mayrhofer, and the rise of germ theory}

intensity of Braun's feelings may also be revealed in the fact that between 1855 and 1881 , he did not mention Semmelweis by name, not even when discussing the views that he had earlier ascribed to Semmelweis. Thus, one should not be surprised that Mayrhofer, Braun's assistant, was reluctant to acknowledge Semmelweis's influence in his own thinking.

In 1865, the year in which Mayrhofer's third essay appeared, A. C. G. Veit observed that in addition to confirming Semmelweis's findings, Mayrhofer's work refuted Braun's opinion that ventilation had a significant influence on the incidence of childbed fever ${ }^{82}$ As we shall see in the next section, Mayrhofer's discovery continued to be regularly cited as a continuation of and as a vindication for Semmelweis's aetiological theory. Indeed, through the next several decades, nearly everyone who mentioned Mayrhofer, and many of those who mentioned Semmelweis, explicitly associated them. As Späth, Veit, and other contemporaries recognized, Mayrhofer's views were much more similar to Semmelweis's than to Braun's. Thus, even in the unlikely event that Mayrhofer himself did not regard his own work as essentially related to Semmelweis's investigations, nearly everyone who subsequently considered their respective accomplishments seems to have felt that this relation was obvious. Moreover, while Braun, as professor of obstetrics and a successful writer, was well known and frequently cited in obstetrical literature, the Semmelweis and Mayrhofer view of childbed fever continued to receive progressively more attention and progressively more favourable attention, while Braun's own view passed into relative oblivion. Given Braun's power and influence in Vienna and his feelings toward Semmelweis, this widespread interpretation of and interest in Mayrhofer's work could certainly explain why, precisely in Vienna, Mayrhofer never received the recognition that he deserved.

\section{IV}

Suppose that we, following several of their associates and successors, think of Semmelweis and Mayrhofer as advocating opinions about childbed fever that were different in detail but similar in essence. It remains to decide whether this opinion exerted a significant influence in the subsequent development of medicine. This is the issue to which we must now turn.

Investigations of childbed fever were much more prominent in the development of germ theory than one might think. Before 1880 , microscopic investigations of tuberculosis, cholera, the exanthemata, and most other infectious diseases had produced only meagre and equivocal results. In the early 1870 s, surveys of literature on the role of bacteria in disease aetiology usually focused on anthrax, undulant fever, and the infected wound diseases.$^{83}$ Investigations carried out in these decades

\footnotetext{
made comments. Did this relate to the fact that after 1850 neither Skoda nor Rokitansky mentioned Semmelweis in lectures-even in lectures on childbed fever-or in their writings?

${ }^{82}$ Veit, op. cit., note 75 above, pp. $195 \mathrm{f}$.

${ }^{83}$ See, for example, Friedrich Steudener, 'Ueber pflanzliche Organismen als Krankheitserreger', Volkmann's klinische Vortäge, Innere Medizin, 1872, 1:283-308; and Felix Victor Birch-Hirschfeld, 'Die neuern pathologisch-anatomischen Untersuchungen über krankmachende Schmarotzerpilze', in Schmidt's Jb. Med., 1872, 155: 97-109; and ibid., 1875, 166: 169-223.
} 


\section{K. Codell Carter}

revealed at least the broad outlines of the aetiologies of anthrax and of undulant fever, and, by the end of the 1870 s, Koch identified these as the best understood of any infectious diseases. ${ }^{84}$ In these decades, however, the infected wound diseases received far more attention in medical periodicals than either anthrax or undulant fever. Indeed, in this period, more than half of all publications on the aetiological significance of bacteria concerned the infected wound diseases. ${ }^{85}$ This was partly due to Pasteur's argument that fermentation was always the result of living ferments and to the general view that organic decomposition, such as one often witnessed in the infected wound diseases, closely resembled fermentation. This made it seem inherently plausible that the infected wound diseases were parasitic. Thus, it is not surprising that writers in the 1880 s regarded germ theory as having originated from investigations of the infected wound diseases. ${ }^{86}$

During the middle of the nineteenth century, childbed fever and so-called surgical fever came to be generally recognized as infected wound diseases. Semmelweis was among the first to advocate this interpretation of childbed fever ${ }^{87}$ By 1860 , even before publication of the Aetiologie, the view that childbed fever was a septic wound infection seems to have been generally associated with Semmelweis. ${ }^{88}$ Perhaps because clinical cases of both diseases were readily available in virtually every hospital, discussions of these two diseases, and especially of childbed fever, became prominent in the literature on infected wound diseases ${ }^{89}$ Thus, given the historical situation and the knowledge available at the time, investigations of puerperal fever proved to be of considerable importance in the development of germ theory. Moreover, during the 1860 s and 1870 s, Semmelweis's work on puerperal fever continued to be discussed in the medical literature; researchers and physicians were beginning to give sympathetic attention to his conception of the disease..$^{90}$

\footnotetext{
${ }^{84}$ Koch made this observation, among other places, in his 1878 paper on the infected wound diseases. See Julius Schwalbe (editor), Gesammelte Werke von Robert Koch, 2 vols., Leipzig, Thieme, 1912, vol. 1, p. 74.

${ }^{85}$ For example, forty-six of eighty-six papers cited in Felix Victor Birch-Hirschfeld's 1875 review of the literature on the occurrence of bacteria in infectious diseases concerned the infected wound diseases (Schmidt's Jb. Med., 1875, 166: 169-223).

${ }^{88}$ See, for example, Maurice Jeannel's history of germ theory in L'infection purulente ou pyohémie, Paris, Baillière, 1880. J. Ravitsch took the same view in his Zur Lehre von der putriden Infection und deren Beziehung zum sogenannten Milzbrande, Berlin, August Hirschwald, 1872.

${ }^{87}$ Semmelweis did not originate this interpretation. In 1837, Eisenmann explained childbed fever as the infection and corruption of wounds by miasmata (op. cit., note 12 above). But Eisenmann believed that the same contagia that produced childbed fever in predisposed puerpera could cause cholera, typhoid, or other diseases in persons with different predispositions. He also believed that the contagia were propagated through the air and constituted miasmata.

${ }^{88}$ W. Roser, 'Die specifische Natur der Pyämie', Arch. Heilk., 1860, 1: 39-50, p. 44. In 1865, a reviewer in Mschr. Geburtsk. Frauenkr., (26:8) observed that the item being reviewed "followed earlier works by Semmelweis, Hirsch, Stamm, Pfeiffer, Bernhardi, and others, on the septic origin of childbed fever". As here, Semmelweis was often cited first in a chronological list of persons who advanced the infectious theory of childbed fever. "Before the time of Semmelweis, the idea of the identity of puerperal fever with pyemia was very far from the minds of the obstetricians, puerperal fever being regarded as something essentially inherent in the relations presented by the puerperal woman." (Junius C. Hoag, 'Puerperal fever and its treatment', Am. J. Obstet. Dis. Wom., 1887, 20: 828-844, 941-957.)

${ }^{89}$ In papers to be cited below, which were among the most important early publications on the infected wound diseases, Wilhelm Waldeyer, Leon Coze, Victor-Timothee Feltz, Louis Pasteur, and Robert Koch all discussed childbed fever.
} 
Carl Mayrhofer's investigations were correct in conception and, given existing technology, sound in execution; and, while they may not have been given the recognition they deserved, they were known and discussed. Mayrhofer's first two papers were reported or abstracted in several Viennese medical periodicals and in the Zentralblatt für die medizinische Wissenschaften. ${ }^{91}$ In 1864, before Mayrhofer's third essay appeared, his discovery of vibrions was confirmed in investigations conducted by $\mathrm{H}$. Fischer at the Charité in Berlin. ${ }^{92}$ However, Fischer "found no indication that [the vibrions] were profoundly significant for the origin of the disease as Mayrhofer assumed." Fischer reported that he and his chief, Ludwig Traube, were more inclined to regard the vibrions "as the bearers of fermentation and alkaline processes". ${ }^{93}$ Fischer reported that vaginal discharges from diseased women regularly contained various organisms. He also reported that the same "plant and animal parasites could be observed in the delivery fluids of healthy maternity patients".

In the following year, Mayrhofer's views were mentioned in connexion with a paper on epidemic puerperal fever. ${ }^{94}$ The paper was delivered by a doctor Kaufmann in the annual meeting of the Deutsche Naturforscher und Aerzte. After mentioning Semmelweis, Kaufmann rejected the possibility of a septic infectious matter, and endorsed, instead, a miasmatic explanation of childbed fever. However, according to the published report, "Veit (Bonn), [Franz Karl Ludwig Wilhelm] Winckel (Rostock), Pernice (Greifswald), and [Eduard] Martin (Berlin), were inclined to the infectious theory. Martin mentioned Mayrhofer's theory of vibrions, and Mankiewitz (Muhlhausen) referred to the injuries to genitals, particularly in operations with forceps."95 Thus, all those who are reported as having responded to Kaufmann's lecture favoured the infection theory, and Mayrhofer was explicitly mentioned. This report appeared in the same issue of the Monatsschrift für Geburtskunde that contained Veit's article, discussed above, in which Mayrhofer was mentioned and associated with Semmelweis. ${ }^{96}$ In the same year, 1865, Mayrhofer's third essay appeared; it too was cited in general reviews of medical literature. ${ }^{97}$

\footnotetext{
${ }^{90}$ For example, in 1864 , Stamm's paper was discussed at the thirty-ninth meeting of the Deutscher Naturforscher und Aerzte (see note 62 above). Stamm observed that world medical literature had now confirmed Semmelweis's claim that childbed fever could be spread by unclean hands, but, in harmony with Braun, Stamm himself believed that ventilation was more important. According to the published report, the paper generated lively discussion. The report concludes, "in the discussion Dr. Stamm responded that it was absolutely not his intention to contest the possibility of infection by unclean hands, instruments etc. On the contrary, he regarded it as a crime to examine with other than clean hands." (Ibid., p. 256.) This conclusion and other remarks reported from the discussion suggest that there was a strong sentiment in the meeting in favour of Semmelweis's theory of infection. More examples of favourable reactions to Semmelweis's work are given below.

${ }^{91}$ Zentbl. med. Wiss., 1863, 1: 144, 349f. And see above, notes 27 and 29.

${ }^{92} \mathrm{H}$. Fischer, 'Bericht über die während des Zeitraums vom 1 Oktober 1862 bis Ende März 1864 auf der innern Abtheilung des Herrn Prof. Traube in der Charité vorgekommenen Puerperal-Erkrankungen', Annln charité-Krankenh. Berlin, 1864, 12: 52-126.

${ }^{93}$ Ibid., p. 119.

${ }^{94}$ The most complete report of Kaufmann's paper appeared in the Mschr. Geburtsk. Frauenkr., 1865, 26: 422-424.

95 Ibid., p. 424.

${ }^{96}$ See note 75 above.

${ }^{97} \mathrm{See}$, for example, Wilhelm Waldeyer's review of the literature in Canstatts Jbr. Fortschr. ges. Med., 1875, 1: 117 .
} 
In 1866, Winckel published the first edition of his Die Pathologie und Therapie des Wochenbettes. ${ }^{98}$ His detailed historical account of various theories of childbed fever concluded with a favourable summary of Semmelweis's views. Winckel mentioned Lange's endorsement of Semmelweis and noted that this opinion had been opposed by Skoda, Karl Rokitansky, and Johann Oppolzer of the Vienna school. ${ }^{99} \mathrm{He}$ also discussed and agreed with Veit's conclusion that prevention of the disease depended less on ventilation than on absolute cleanliness-a view Winckel had already supported in the discussion of Kaufmann's paper one year earlier. ${ }^{100}$ Near the end of his account, Winckel gave detailed and positive attention to Mayrhofer's work and to other publications associated with it. Winckel stressed "the noteworthy fact that Mayrhofer has also come to the conclusion "that it is ordinarily the examining finger that conveys vibrions into the uterus'."101

In the same year, 1866, Leon Coze and Victor-Timothee Feltz mentioned Mayrhofer in a historical survey that initiated one of their series of highly influential studies of infected wound diseases. ${ }^{102}$ In 1866 and 1867, Semmelweis's animal experiments were also cited by various German scientists who were investigating infected wound diseases. ${ }^{103}$ In one essay, W. Roser observed that Semmelweis's conception of childbed fever had become a dominant position among obstetricians and that even many surgeons had been converted to the doctrine. ${ }^{104}$

In a long study of diseases of the female sexual organs, published in 1867, Veit noted that "the old idea of miasmatic contagion was first challenged by Semmelweis. He taught that childbed fever was a resorption fever occasioned by infection with decaying organic matter. This view is penetrating ever greater circles and, in a short time, will find no more opponents." $105 \mathrm{He}$ pointed out that inadequate ventilation could not be important in the spread of the disease. ${ }^{106} \mathrm{He}$ also noted that since childbed fever was the result of a septic infection, it was essential to establish the exact nature of the septic poison. He mentioned Mayrhofer's work as a possible solution to this problem. ${ }^{107}$ In 1867 , Mayrhofer was also mentioned in a general

\footnotetext{
${ }^{98}$ Franz Karl Ludwig Wilhelm Winckel, Die Pathologie und Therapie des Wochenbettes, Berlin, Hirschwald, 1866. Other editions, which appeared in 1869 and 1878, retained the references to Mayrhofer and to Semmelweis.

${ }^{99}$ Ibid., p. 264. Of course, Winckel's comments further undercut the dominant view that Skoda and Rokitansky were Semmelweis's ardent supporters.

${ }^{100}$ Loc. cit., note 95 above.

${ }^{101}$ Winckel, op. cit., note 98 above, pp. $274 \mathrm{f}$.

${ }^{102}$ Leon Coze and Victor-Timothee Feltz, 'Recherches expérimentales sur la présence des infusoires et l'état du sang dans les maladies infectieuses', Gaz. méd. Strasb., 1866, 2nd series, 6: 61-64, 115-125, 208f, 225-229, p. 62.

${ }^{103}$ For example, Franz Schweninger, 'Ueber die Wirkung faulender organischer Substanzen auf den lebenden thierischen Organismus', Aerztl. Intell.-bl., 1866, 13: 590-598, 612-616, 623-627, 636-641, 654-659, 668-672, pp. 591, 597; and Roser, 'Zur Verständigung über den Pyämiebegriff', Arch. Heil., 1867, 8: 15-24, pp. 17, 20 f.

${ }^{104}$ Ibid., p. 20. Other writers also referred to "adherents of the Semmelweis view", clearly suggesting that Semmelweis's theory, not just the prophylactic measures, had numerous supporters. See, for example, Emil Neumann, 'Puerperalerkrankungen in Schwezingen und seiner Umgebung in den Jahren 1863-1865', Mschr. Geburtsk. Frauenkr, 1866, 28: 442-452, p. 442.

${ }^{105}$ Gustav Veit, Krankheiten der weiblichen Geschlechtsorgane, Erlangen, Ferdinand Enke, 2nd ed., 1867, p. 678. This was one volume in Virchow's multi-volumed Handbuch der speciellen Pathologie und Therapie.

${ }^{100}$ Ibid., p. 702.

${ }^{107}$ Ibid., p. 703. The first edition of Veit's book, published in 1864, did not mention Mayrhofer.
} 
review of literature on the aetiological significance of micro-organisms. ${ }^{108}$

In 1868, David Haussmann of Berlin published a provisional announcement of work which, he claimed, counted against certain details in Mayrhofer's position. Haussmann reported finding vibrions in the lochial discharge of healthy maternity patients and even of non-maternity patients. ${ }^{109}$ Haussmann's paper was widely cited and he was often said to have refuted Mayrhofer by showing that vibrions were present in the lochial discharge of healthy patients. In fact, in each of his publications, Mayrhofer pointed out that vibrions could be found in discharges from healthy patients. Haussmann claimed only to have found the vibrions earlier than five days after delivery. As Haussmann himself made clear in his later papers, his disagreement concerned details. His investigations should have been understood as supporting Mayrhofer's general position. ${ }^{\mathbf{1 1 0}}$

The same issue of the Monatsschrift für Geburtskunde that abstracted Haussmann's paper contained an essay by Max Boehr entitled 'On the infection theory of puerperal fever and its consequences for public health officials'. ${ }^{111}$ The paper was originally presented before the Gesellschaft für Geburtshilfe in Berlin. The entire paper drew heavily on Semmelweis's work and conclusions. Boehr noted that "the theory of infection has the characteristic of all good pathological and physiological theories; it provides a unified, clear, and entirely intelligible meaning for a whole series of anatomical and clinical facts and for the relevant experiences and discoveries of reliable observers during epidemics. None of the earlier or alternative hypotheses or theories regarding the occurrence of childbed fever has this characteristic to the same degree."112 Boehr mentioned that in the Aetiologie, Semmelweis had expanded his earlier opinion to include, as causally significant, every kind of putrid matter from living diseased organisms as well as from cadavers. This made it possible for Semmelweis to explain every case of childbed fever. "In this way, the superstitions [Wunderglaube] of our predecessors, who believed in

\footnotetext{
${ }^{108}$ Hermann Eberhard Richter, 'Die neuern Kenntnisse von den krankmachenden Schmarotzerpilzen', Schmidt's Jb. Med., 1867, 135: 81-98, p. 95.

${ }^{109}$ David Haussmann, 'Zur Aetiologie des Wochenbettfiebers', Zentrbl. med. Wiss., 1868, 6: 418-420, p. 419. In each of his papers, Mayrhofer mentioned that he occasionally found vibrions in vaginal discharges from healthy patients. However, in healthy women he did not identify vibrions until at least five days after delivery, and he believed that normally acidic vaginal secretions helped protect women from invasion. Haussmann claimed to find vibrions after only three-and-one-half days and, in some cases, to have found them even in acidic secretions. Some subsequent authors took Mayrhofer to have been claiming that the vibrions were a sufficient cause and, overlooking his explicit reports that vibrions could occasionally be found in healthy patients, concluded that Haussmann's observations counted significantly against Mayrhofer's results. See, for example, Birch-Hirschfeld (1872), op. cit., note 83 above, p. 105; and Wilhelm Waldeyer, 'Ueber das Vorkommen von Bacterien bei der diphtheritischen Form des Puerperalfiebers', Arch. Gynaek., 1872, 3: 293-296, p. 294. Given that these influential researchers misconstrued the relation between Mayrhofer and Haussmann in this way, one must suspect that comparable misunderstandings contributed to the general tendency to undervalue Mayrhofer's work.

${ }^{110}$ Haussmann's work was carried out under Eduard Martin's direction, and Martin had expressed his commitment to the infectious theory three years earlier. See note 95 above. Mayrhofer was regularly mentioned in discussions of Haussmann's work. For example, see the abstract of Haussmann's essay in Mschr. Geburtsk. Frauenkr., 1868, 32: 144.

${ }^{111}$ Max Boehr, 'Ueber die Infectionstheorie des Puerperalfiebers und ihre Consequenzen für die Sanitäts-Polizei', ibid., 1868, 32: 401-433.

${ }^{112}$ Ibid, p. 403. This is a remarkably perceptive and concise statement of the criteria for choosing among alternative scientific theories.
} 


\section{K. Codell Carter}

unknown cosmic-telluric-atmospheric influences, were dealt a severe blow, as was the belief in miasmata, which belief was, of course, more similar to the infectious theory." 113 Boehr here identified the essential steps in Semmelweis's aetiological strategy. Boehr cited Veit, Späth, and Mayrhofer, as well as others who had supported the infection theory. Finally, Boehr considered various legal measures to improve cleanliness in maternity hospitals.

The Monatsschrift also reported the discussion of Boehr's paper. The report included comments by Max Wegscheider, David Haussmann, Eduard Martin, and three other physicians identified as Scharlau, Krieger, and Ebell. Only Ebell is reported as having said anything opposed to the infection theory; his comment was that "in addition to contagiousness, there are still other causes of puerperal fever". ${ }^{114}$ According to the report, "Boehr responded that in addition to artificial infection from external sources, he himself recognized only self-infection through foul matter from the patient herself." In this comment, Boehr acknowledged decaying organic matter as a necessary cause in every case of childbed fever. The other participants had reservations about the appropriateness of legal regulations on the medical profession, but they did not object to Boehr's discussion of childbed fever. Thus, with the possible exception of Ebell, no one in the Berlin society is reported as having opposed Boehr's account, an account based on the aetiological strategy that Semmelweis and Mayrhofer employed and that had been universally rejected at the time Semmelweis first adopted it.

Over the next few years, Semmelweis and Mayrhofer were mentioned favourably in several publications. ${ }^{115}$ Beginning in 1872 , they were cited in both French and German papers that proved to be among the most influential of the early contributions to germ theory. During the 1860 s, Coze and Feltz conducted studies of infectious diseases that resulted in many publications and culminated in their Recherches cliniques et expérimentales sur les maladies infectieuses, ${ }^{116}$ a book frequently cited by Pasteur and Koch. The chapter on puerperal sepsis began with a discussion of Semmelweis. Friedrich Wieger and Franz Hektor Arneth, two of Semmelweis's students in the first clinic and eye-witnesses to his discoveries, published the first French accounts of Semmelweis's work; both were cited by Coze and Feltz. ${ }^{117}$ One page later, Coze and Feltz acknowledged that Mayrhofer had been the first to identify vibrions in the lochial discharge of victims of puerperal fever.

Also in 1872, in an article in the German periodical Archiv für Gynaekologie, Wilhelm Waldeyer of Breslau mentioned that Mayrhofer had been the first to identify bacteria in puerperal fever victims. ${ }^{118}$ Three years later, Felix Victor BirchHirschfeld identified Waldeyer's paper as one of four that had been most influential

\footnotetext{
${ }^{113}$ Ibid., p. 404.

114 Ibid., p. 433.

${ }^{115}$ For example, Rudolf H. Ferber, 'Die Aetiologie, Prophylaxis und Therapie des Puerperalfiebers', Schmidt's Jb. Med., 1868, 139: 318-346; David Haussmann, Die Parasiten der weiblichen Geschlechtsorgane, Berlin, August Hirschwald, 1870; and Arch. Gynaek., 1870, 1: 518.

${ }^{116}$ Leon Coze and Victor-Timothee Feltz, Recherches cliniques et expérimentales sur les maladies infectieuses, Paris, Baillière, 1872.

${ }^{117}$ Ibid., pp. 259, 261.

${ }^{118}$ Waldeyer, op. cit., note 109 above.
} 


\section{Semmelweis, Mayrhofer, and the rise of germ theory}

in awakening interest in the infected wound diseases. ${ }^{119}$ In 1873, Johannes Orth published an important discussion of puerperal fever in Virchows Archiv. ${ }^{120}$ This discussion began with a careful and sympathetic review of Mayrhofer's findings. In discussing Mayrhofer's animal experiments, Orth mentioned that Mayrhofer had attempted to use pure cultures to show that the vibrions caused the disease. "Remarkably enough", Orth observed, "this obvious and conclusive experiment was not sufficiently appreciated and in the next few years there was almost no subsequent research." Orth also mentioned Fischer's confirmation of the factual aspects of Mayrhofer's work and pointed out that Haussmann purported to oppose Mayrhofer but hadn't bothered to repeat Mayrhofer's experiments. ${ }^{121}$

One year later, in 1874, Haussmann published two accounts of animal experiments that were intended to verify the similar animal experiments that Semmelweis and Mayrhofer had conducted. ${ }^{122}$ Haussmann mentioned that he had delayed publication of these results only because, at the time he conducted the experiments, there had been general hostility to attempts to establish the causal significance of micrococci. ${ }^{123}$ In these publications, Haussmann clearly regarded himself as in general agreement with Mayrhofer and Semmelweis. ${ }^{124}$ Also in 1874, Carl Rokitansky, jun., published an examination of the microscopic constituents of lochial discharges. He mentioned Mayrhofer as the first to have examined the occurrence of bacteria in lochial discharges and, while he disputed some details, ${ }^{125}$ he supported Mayrhofer's general position.

In 1875, Mayrhofer was cited in Birch-Hirschfeld's important review of literature on micro-organisms as disease agents. ${ }^{126}$ In 1877, Mayrhofer's results were mentioned in Birch-Hirschfeld's widely used textbook on pathological anatomy. ${ }^{127}$ One year after the appearance of this textbook, Robert Koch published his essay on the infected wound diseases. Koch relied heavily on Birch-Hirschfeld's review of the literature and on his textbook. ${ }^{128}$ Koch also cited the papers by Waldeyer and

\footnotetext{
${ }^{119}$ Birch-Hirschfeld, op. cit., note 83 above, p. 171.

${ }^{120}$ Johannes Orth, 'Untersuchungen über Puerperalfieber', Virchows Arch. path. Anat. Physiol., 1873, 58: $437-460$.

${ }^{121}$ Ibid., pp. 437f. Orth also mentioned Mayrhofer in 'Untersuchungen über Erysipel', Arch. exp. Path. Pharmak., 1873, 1: 81-137, p. 83. Mayrhofer and Semmelweis were also mentioned by French writers in this period, for example, Leon Billet, De la fièvre puerpérale et de la réforme des maternités, Paris, Baillière, 1872, pp. 20, 28; and H.-A. D'Espine, Septicémie puerpérale, Paris, Baillière, 1873, pp. 13, 139.

${ }^{122}$ David Haussmann, 'Zur Aetiologie des Wochenbettfiebers', Zentbl. med. Wiss., 1874, 12: 433-437, p. 433; idem, 'Untersuchungen und Versuche über die Entstehung der übertragbaren Krankheiten des Wochenbettes', Beitr. Geburtsh. Gynäk., 1874-5, 3: 311-421.

${ }^{123}$ Compare this comment from one of Mayrhofer's obituaries (op. cit., note 23 above, c. 779): “At that time, most experts regarded microscopic investigations, especially those concerning the smallest organisms, with a kind of sovereign contempt."

${ }^{124}$ See, for example, Haussmann's positive discussion of both Semmelweis and Mayrhofer on pages $311 \mathrm{f}$ and 315 of the second essay cited in note 122 above.

${ }^{125}$ Carl Rokitansky, jr., 'Untersuchungen der mikroskopischen Zusammensetzung der Lochien', Med. $J b ., 1874$, 30: 161-178. Like Haussmann, Rokitansky objected mainly to Mayrhofer's claim that microorganisms were not found in healthy vaginal discharges until the fifth day after delivery.

${ }^{126}$ Birch-Hirschfeld (1875), op. cit., note 83 above, p. 171.

${ }^{127}$ Felix Victor Birch-Hirschfeld, Lehrbuch der pathologischen Anatomie, Leipzig, Vogel, 1877, pp. $1141 \mathrm{f}$.

${ }^{128}$ Robert Koch, 'Untersuchungen über die Aetiologie der Wundinfektionskrankheiten', reprinted in Schwalbe, op. cit., note 84 above, vol. 1, pp. 61-108. Koch cited Birch-Hirschfeld's textbook eight times in this essay, and most of the other sources that Koch discussed were cited in Birch-Hirschfeld's review.
} 


\section{K. Codell Carter}

Orth. ${ }^{129}$ In his studies of puerperal fever, Pasteur also cited Waldyeyer and Orth. ${ }^{130}$ Thus, both Pasteur and Koch cited both French and German authors who discussed Mayrhofer's findings. While neither Pasteur nor Koch mentioned either Mayrhofer or Semmelweis, Mayrhofer was mentioned in a history of bacteriology written by Friedrich Löffler, Koch's associate and colleague. ${ }^{131}$

In 1883, in the second edition of his Handbook of geographical and historical pathology, August Hirsch claimed credit for having discovered Semmelweis at a time (the 1860s) when German physicians were supposedly giving him relatively little attention. Hirsch wrote, "I thus share with Semmelweis the credit of being named a founder of the rational theory of the origin of puerperal fever." ${ }^{132}$ At about the same time, M. Wertheimer wrote, "The earlier theory of the miasmatic nature of [childbed fever], as taught and developed by Eisenmann, Helm, Litzmann, Kiwisch, Scanzoni, and others, was first put on the right track by Semmelweis. . . . His theory was soon supported, expanded, and confirmed by a series of authors such as Alfred Hegar, Buhl, Winkel, Fischer, Veit, Mayrhofer."'133

Semmelweis and Mayrhofer were cited in German, French, and English sources into the last decade of the century. ${ }^{134}$ However, as the theoretical and experimental aspects of germ theory developed, their studies became progressively less relevant to current issues, and references to them became progressively less common.

How, then, are we to appraise the significance of Semmelweis's influence in the rise of germ theory? One might certainly object that most of the above is circumstantial. There is no conclusive evidence that Mayrhofer was positively influenced by Semmelweis-he never mentioned Semmelweis in any of his publications. Moreover, while researchers like Waldeyer, Orth, Birch-Hirschfeld, Coze, and Feltz did cite Semmelweis or Mayrhofer, it does not follow that they were actually influenced by them. Citations establish awareness but may not prove influence.

Nevertheless, the preceding discussion proves that by the mid-1860s, Semmelweis's conception of childbed fever was very widely known. As one contemporary physician observed, it had become part of the common property of a whole generation of medical personnel. ${ }^{135}$ By the 1870 s, all prominent researchers must at least have been aware of Semmelweis's theoretical approach. In these years,

\footnotetext{
${ }^{129}$ Ibid., pp. $65,67$. 133.

${ }^{130}$ Pasteur Vallery-Radot (editor), Oeuvres de Pasteur, 7 vols., Paris, Masson, 1922-39, vol. 6 (1933), p.

${ }^{131}$ Friedrich Löffler, Vorlesungen über die geschichtliche Entwicklung der Lehre von den Bacterien, Leipzig, Vogel, 1887, p. 89.

${ }^{132}$ Hirsch, op. cit., note 58 above, p. 320. The accuracy of this claim is not in question here.

${ }^{133} \mathrm{M}$. Wertheimer, Von dem Verhalten der Lochialsecretion zur Pathogenese des Kindbettfiebers, Freiburg i.B., H. M. Poppen, 1888, pp. 5f.

${ }^{134}$ For example, Paul Bar, Des méthodes antiseptiques en obstétrique, Paris, Coccoz, 1883; Lomer, 'Ueber den heutigen Stand der Lehre von den Infectionsträgern bei Puerperalfieber', Z. Geburtsh. Gynäk., 1884, 10: 366-397, pp. 366, 369; and W. W. Jaggard, 'The pathology, aetiology, prophylaxis, and treatment of puerperal fever, from the Vienna standpoint', Med. News, 1884, 44: 442-445, 467f; 1885 , 45: $179 f$, p. 443.

${ }^{135}$ Wilhelm Fischel, 'Zur Therapie der puerperalen Sepsis', Arch. Gynaek., 1882, 20: 1-70, p. 1.
} 
it became apparent that other diseases such as anthrax and undulant fever could also be ascribed to universal necessary causes. We have seen that investigations of the infected wound diseases-especially of childbed fever-were prominent in earlier literature on the aetiological significance of micro-organisms. Given all this, Semmelweis's well-known theoretical position and Mayrhofer's investigations must at least have contributed to the plausibility of germ theory and have encouraged the attempt to assimilate other diseases to that model. Apart from any direct positive influence, therefore, one can certainly claim that Semmelweis's aetiological strategy constituted an important part of the background conditions in which late nineteenthcentury medical research was conducted. To use a modern term, Semmelweis's contributions, and to a lesser extent Mayrhofer's as well, were a significant part of the late nineteenth-century medical research programme. In this sense, at the very least, Semmelweis's work contributed importantly to the theoretical development of germ theory. 